\title{
Subsurface Fluid Injection and Energy Storage
}

Q. Li, M. Kühn (Guest editors)

\section{Subsurface fluid injection and energy storage}

\author{
Qi $\mathrm{Li}^{1,2, *}$ (D) and Michael $\mathrm{Kühn}^{3,4}$ \\ ${ }^{1}$ State Key Laboratory of Geomechanics and Geotechnical Engineering, Institute of Rock and Soil Mechanics, \\ Chinese Academy of Sciences, Wuhan 430071, China \\ ${ }^{2}$ University of Chinese Academy of Sciences, Beijing 100049, China \\ ${ }^{3}$ GFZ German Research Centre for Geosciences, Fluid Systems Modelling, Potsdam 14473, Germany \\ ${ }^{4}$ University of Potsdam, Institute of Geosciences, Potsdam 14476, Germany
}

Accepted: 17 August 2021

In the current global environmental problems, reducing $\mathrm{CO}_{2}$ emissions is an important goal and guide for countries all over the world in developing environmental and economic policies. It has become a global consensus to jointly promote greenhouse gas emission reduction. From 1970 to 2004, $\mathrm{CO}_{2}$ emissions increased yearly, accounting for $76 \%$ of the total emissions in 2004. According to the prediction of the International Energy Agency (IEA), the total global $\mathrm{CO}_{2}$ emission reached a record of 30 billion tons in 2010 . In 2005, the Intergovernmental Panel on Climate Change (IPCC) specially recommended Carbon Capture and Storage (CCS) technology to achieve significant emission reduction of greenhouse gases. In 2007, the World Wide Fund for Nature (WWF) identified CCS as one of the six ways to deal with global climate change. The global climate conference in Cancun in 2010 incorporated CCS into the Clean Development Mechanism (CDM). The United States, Canada, the European Union, and other countries have taken CCS as an important part of future energy strategies and carbon emission reduction strategies and have formulated corresponding technology research plans that include Research and Development (R\&D) and project demonstration. The NET-Zero Emissions (NZE) scenario proposed by the IEA for 2050 puts global $\mathrm{CO}_{2}$ capture at 1.7 gigatonnes per year in 2030 and 7.6 gigatonnes per year in 2050. Presently, CCS is a hot topic all around the world.

According to the statistical analysis of the articles published in Oil \& Gas Science and Technology - Revue d'IFP Energies Nouvelles in the last 5 years (2014-2019), there are a total of 64 articles related to the CCS research field. In the resulting list, the most cited popular papers are related to policy issues, migration front capture, and analysis of geochemical reaction. To be more specific, the three most cited articles are:
1. A review on $\mathrm{CO}_{2}$ hydrogenation to methanol [1].

2. An experimental study for choosing suitable carbon storage sites based on the connectivity and the porestructure separation [2].

3. A strategy for monitoring whether $\mathrm{CO}_{2}$ is safely sequestered [3].

The other entries treat other essential topics such as flow mechanism studies, $\mathrm{CO}_{2}$ injection processes, development of new materials for oil exploration, induced seismic studies, and PVT analysis of $\mathrm{CO}_{2}$-petroleum systems.

In fact, $\mathrm{CO}_{2}$ gas from industrial waste gas is obtained and transported by truck or pipeline to the storage site, and then heated and pressurised at the surface and injected into the reservoir. $\mathrm{CO}_{2}$ in factories often contains other impurities that are different from the physical chemistry of pure $\mathrm{CO}_{2}$. The suitable target reservoir mainly contains deep saline aquifer, abandoned oil/gas reservoirs, coalbed methane reservoirs, and deep ocean. At the same time, $\mathrm{CO}_{2}$ can also be used as a source of energy that can help in oil shale gas development, uranium mining, geothermal exploitation and act as a cushion gas for the power-to-gas project. To accurately calculate the carbon storage capacity and utilization efficiency, the reservoir injectivity, the stability of the reservoir cap and the storage safety should be taken into account in the carbon injection project. Significant scientific and technical challenges must be solved to securely and safely develop subsurface fluid injection and energy storage. Once $\mathrm{CO}_{2}$ is injected underground, the key scientific questions are listed below:

- Capture the migration front of subsurface fluids, especially in heterogeneous formations.

- Evaluate the effect of geochemical reactions on the physical structure of the formation.

- Reveal the mechanism of fluid-solid coupling during injection and post-injection stages.

- Analyse the influence of stratigraphic structures (such as faults) on the safety and stability of storage.

\footnotetext{
* Corresponding author: qli@whrsm.ac.cn
} 
- Explore the physical and chemical reactions of subsurface fluids with impurities such as $\mathrm{H}_{2} \mathrm{~S}$.

This topical issue with the focus on "Subsurface Fluid Injection and Energy Storage" contributes to the aim of the journal $O G S T$ to publish research in all related fields like exploration and production of petroleum, natural gas, and other sources of energy and in particular alternative energies in view of the energy transition. Ambitious climate and energy targets are set in many countries around the world. To enable the renewable energy resources to become the central pillar of the future energy supply, the utilization of the geological subsurface obtains a new relevance. In this view, especially energy storage is of utmost importance with increasing demands to utilize geological reservoirs. Various manuscripts are collected here which outline the broad field of research in that regard.

Zhang et al. [4] address the impact assessment of interlayers on affecting the heterogeneity of the reservoir in the Songliao Basin, China. This study is beneficial to provide guidance and advice for selecting a suitable $\mathrm{CO}_{2}$ geological storage reservoir. The caprock sealing performance plays a key role in determining permanence and security of $\mathrm{CO}_{2}$ geological storage. Ma et al. [5] present geochemical modeling of $\mathrm{CO}_{2}$-brine-rock interactions in a deep saline aquifer in the Jianghan Basin, Hubei Province, China. Li and Ma [6] reported the influence of pore system change during $\mathrm{CO}_{2}$ storage on $4 \mathrm{D}$ seismic interpretation, and the proposed methodology is expected to be used in China's Shengli Oilfield $\mathrm{CO}_{2}$-EOR project. Zhang et al. [7] used the the TMVR_EOSG module of the TOUGHREACT code to simulate the feasibility of acid gas $\left(59 \% \mathrm{CO}_{2}\right.$ and $41 \%$ $\mathrm{H}_{2} \mathrm{~S}$ ) injection in a carbonate formation of the Tarim Basin, Xinjiang, China. The results could be used as guidance for future acid gas injection operations. Liu et al. [8] used the ECO2N module of the TOUGH2MP simulator to investigate temperature and pressure responses in the geothermal reservoir while considering the cooling effect induced by injection of $\mathrm{CO}_{2}$ and cooled geothermal water. This study enhanced the understanding of low-medium geothermal reservoirs in Binhai district, Tianjin, China. Zhou et al. [9] studied the formation mechanism of authigenic chlorite in tight sandstone and its effect on tight oil adsorption during hydrocarbon filling in Yanchang Formation, southwest region of Ordos Basin, China.

Wei et al. [10] studied fault slippage and its permeability evolution during supercritical $\mathrm{CO}_{2}$ fracturing in layered formation. Major result is that due to limited determined fault slippage in combination with lower initial permeability, the $\mathrm{CO}_{2}$ fracturing operation near undetected small faults could not conduct preferential pathway for upward $\mathrm{CO}_{2}$ leakage or contaminate overlying shallower potable aquifers.

All in all a step forward but further research is needed. The focus will be on the coupled interaction of processes during flow in porous media studied by laboratory and field experiments and numerical simulations. Of specific interest are flooding mechanisms and injectivity, induced seismicity, hydrate formation, wellbore failures, caprock integrity, hydraulic fracturing, risk assessment, etc. Solving each of the issues is intended to make a better understanding of subsurface fluid injection and energy storage projects around the world.

\section{References}

1 Tursunov O., Kustov L., Kustov A. (2017) A brief review of carbon dioxide hydrogenation to methanol over copper and iron based catalysts, Oil Gas Sci. Technol. - Rev. IFP Energies nouvelles 72, 5, 30. https://doi.org/10.2516/ogst/ 2017027.

2 Freire-Gormaly M., Ellis J.S., MacLean H.L., Bazylak A. (2016) Pore structure characterization of Indiana limestone and pink dolomite from pore network reconstructions, Oil Gas Sci. Technol. - Rev. IFP Energies nouvelles 71, 3, 13. https://doi.org/10.2516/ogst/2015004.

3 Beaubien S.E., Ruggiero L., Annunziatellis A., Bigi S., Ciotoli G., Deiana P., Graziani S., Lombardi S., Tartarello M.C. (2015) The importance of baseline surveys of nearsurface gas geochemistry for CCS monitoring, as shown from onshore case studies in northern and southern Europe, Oil Gas Sci. Technol. - Rev. IFP Energies nouvelles 70, 4, 615633. https://doi.org/10.2516/ogst/2014009.

4 Zhang D., Fan C., Kuang D. (2019) Impact assessment of interlayers on geological storage of carbon dioxide in Songliao Basin, Oil Gas Sci. Technol. - Rev. IFP Energies nouvelles 74, 85. https://doi.org/10.2516/ogst/2019059.

5 Ma X., Yang G., Li X., Yu Y., Dong J. (2019) Geochemical modeling of changes in caprock permeability caused by $\mathrm{CO}_{2}^{-}$ brine-rock interactions under the diffusion mechanism, Oil Gas Sci. Technol. - Rev. IFP Energies nouvelles 74, 83. https://doi.org/10.2516/ogst/2019055.

6 Li L., Ma J. (2019) The influence of pore system change during $\mathrm{CO}_{2}$ storage on $4 \mathrm{D}$ seismic interpretation, Oil Gas Sci. Technol. - Rev. IFP Energies nouvelles 74, 81. https://doi.org/10.2516/ogst/2019047.

7 Zhang X., Li Q., Zheng L., Li X., Xu L. (2020) Numerical simulation and feasibility assessment of acid gas injection in a carbonate formation of the Tarim Basin, China, Oil Gas Sci. Technol. - Rev. IFP Energies nouvelles 75, 28. https://doi.org/10.2516/ogst/2020019.

8 Liu H., Li Q., Gou Y., Zhang L., Feng W., Liao J., Zhu Z., Wang H., Zhou L. (2020) Numerical modelling of the cooling effect in geothermal reservoirs induced by injection of $\mathrm{CO}_{2}$ and cooled geothermal water, Oil Gas Sci. Technol. - Rev. IFP Energies nouvelles 75, 15. https://doi.org/10.2516/ ogst $/ 2020005$.

9 Zhou Q., Li C., Chen G., Lyu C., Qu X., Ma X., Li C., Lei Q., Xie Q. (2021) The formation mechanism of authigenic chlorite in tight sandstone and its effect on tight oil adsorption during hydrocarbon filling, Oil Gas Sci. Technol. - Rev. IFP Energies nouvelles 76, 39. https://doi.org/ $10.2516 /$ ogst $/ 2021015$.

10 Wei X., Zhang J., Li Q., Liu X., Liang L., Ran L. (2019) Fault slippage and its permeability evolution during supercritical $\mathrm{CO}_{2}$ fracturing in layered formation, Oil Gas Sci. Technol. - Rev. IFP Energies nouvelles 74, 76. https://doi. org/10.2516/ogst/2019051. 